\title{
How Useful Are Banks' Earnings-At-Risk And Economic Value Of Equity-At-Risk Public Disclosures?
}

Jacques Préfontaine, (Email: jprefontaine@adm.usherbrooke.ca), Université de Sherbrooke, Canada Jean Desrochers, (Email: jdesrochers@adm.usherbrooke.ca), Université de Sherbrooke, Canada

\begin{abstract}
This paper examines the information content and the usefulness of banks' interest rate risk public disclosures. ALM managers use Earnings at Risk ( EAR) and Economic Value of Equity at Risk ( EVEAR ) as measures of the dollar amount of potential loss to net interest income and common shareholders' equity as a result of unforeseen interest rate changes. These two interest rate risk management metrics are now recognized benchmarks for measuring interest rate risk exposure, and its potential impact on a bank's financial position. At the explicit request of regulators, financial analysts and competitive pressures, more commercial banks are now reporting EAR and EVEAR numbers in their annual financial reports. To examine preliminary evidence on the information content of such public disclosures, we composed a sample of some of North America's largest commercial banks. The Canadian peer group is based on Canada's seven largest banks, and the U.S. peer group is composed of twelve of its largest banks. In particular, we investigate if "ex ante" EAR and EVEAR numbers help regulators, financial analysts and investors to explain the subsequent variability of commercial banks' net interest income and net income over time.
\end{abstract}

\section{INTRODUCTION}

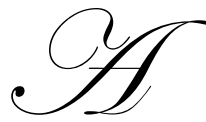

LM managers use Earnings at Risk (EAR) and Economic Value of Equity at Risk (EVEAR) as measures of the dollar amount of potential loss to net interest income and common shareholder's equity as a result of unforeseen interest rate changes. These two interest rate risk managerment metrics are now recognized benchmarks for measuring the non-trading exposure to interest rate risk, and its potential impact on a bank's financial position. Similarly, the Value at Risk (VAR) measure is the recognized benchmark for measuring the trading exposure to all market risks, including interest rate risk, and its potential impact on a bank's financial position.

At the explicit request of regulators, financial analysts and competitive pressures, more internationally active commercial banks are now reporting EAR and EVEAR numbers in their annual financial reports. Lopez (2003) explains the ongoing international efforts to improve the regulation and supervision of banking institutions to reflect advances in financial risk management techniques. His analysis supports the view that improved public disclosures regarding their conditions, operations and risk management information lead to increased transparency and should lead to more effective market discipline.

The evolution of bank disclosure standards in the United States has been described in a study published by the BGFRS (2000). The SEC and the FASB together set the core disclosure requirements for publicly traded banks. Moreover, all banks in the U.S. are required to file quarterly regulatory reports.

In a recent publication, the Basel Committee on Banking Supervision (BCBS, 2003) provides an overview of the disclosure practices of a sample of internationally active commercial banks. The BCBS survey focuses on the annual reports of 54 banks headquartered in the committee's member counties. It included 104 questions addressing quantitative and qualitative disclosures in 4 various categories: capital adequacy, market risk internal modeling, 
derivatives, accounting and presentation policies The survey reveals that many banks have continued to expand the extent of their disclosures. The main findings of the disclosure survey that relate more directly to the focus of this study are the following: Firstly, disclosure of information on internal risk models was much more common for market risk than for credit risk. Secondly, the most noteworthy improvement is the increase in the disclosure of information on other risks (operational and legal risks, liquidity risk and interest rate risk in the banking book (non-traded). Thirdly, regarding individual disclosure items, the survey results indicate that market risk internal modeling (e.g. the type used) was one of the most common items disclosed.

The rest of the paper is structured as follows: section two defines the EAR and EVEAR non-trading exposure measures; the VAR trading exposure measure is also examined as well as its predictive power. The third section describes the research methods, the bank sample data, and formulates hypotheses on the usefulness of EAR and EVEAR numbers to explain the subsequent variability of commercial banks' earnings and economic value of equity. Section four presents and discusses the study's empirical results. Finally, the conclusion, limits of the study and suggestions for further research are drawn in the fifth section.

\section{IMPROVED MARKET RISK INFORMATION DISCLOSURES}

Recently, several authors have examined if improved market risk information disclosures lead to increased transparency and more effective market discipline. Wong (2000) studied the association between SFAS no. 119 derivatives disclosures and the foreign exchange risk exposure of manufacturing firms. Christofferson, Hahn and Inoue (2001) tested, compared and combined value at risk measures. Berkowitz and O'Brien (2001) evaluated the accuracy of VAR at commercial banks. In another study, Linsmeier, Thornton, Venkatachalan and Welken (2002) analyzed the effect of mandated market risk disclosure on trading volume sensitivity to interest rate, exchange rate and commodity price movements.

Of more direct importance to the focus of this study, Lopez (2003) summarizes the conclusion of a case study reported by the BGFR (2000) regarding SEC requirements for disclosure of market risk exposures. The author defines market risk exposures as potential financial losses due to adverse movement in securities market prices. Most often, commercial banks report such risks with value-at-risk (VAR) estimates that summarize the potential losses that might occur with a specified probability ( $95 \%$ or $99 \%$ of the time) over a given time horizon like one or 10 trading days. A bank disclosing, for example, that its daily VAR is $\$ 25$ million at the $99 \%$ level, indicates that there is only a $1 \%$ chance the bank will incur more than a $\$ 25$ million trading loss over the next day. "In the case study, bank VAR disclosures were found to vary in detail across banks and to have an unclear connection with actual trading performance during the turbulent third quarter of 1998". The author finds that even though such heterogeneity is present in these types of public disclosures, the academic literature still suggests that market participants can assess bank risks accurately.

In another more recent study of VAR disclosures, Jorion (2003) found that VAR numbers in quarterly and annual reports, from 1995 to 2000, of 8 publicly traded U.S. commercial banks provided reasonable predictions of the subsequent variability of their trading revenues. Thus, the empirical results presented in the Jorion study suggest that VAR disclosures are informative in that they predict the variability of trading revenues. Thus, analysts and investors can use VAR disclosures to compare the risk profiles of banks' trading portfolios.

Figure 1 shows an example of Sun Trust Banks' EAR and EVEAR disclosures. Notice that this bank uses Net Interest Income-at-Risk instead of the more common EAR measure; nevertheless, both measures are compatible. In addition, management's discussion provides valuable disclosures into the interest risk modeling process at Sun Trust Banks. 
FIGURE 1: Excerpts from the Annual Report of Sun Trust Banks, 2002, pp. 37-38, Management's Discussion of Market Risk from Non-Trading Activities.

\section{Market Risk Management}

Market risk refers to potential losses arising from changes in interest rates, foreign exchange rates, equity prices, commodity prices and other relevant market rates or prices.

Interest rate risk, defined as the exposure of net interest income and Economic Value of Equity (EVE) to adverse movements in interest rates, is SunTrust's primary market risk, and mainly arises from the structure of the balance sheet (non-trading activities). SunTrust is also exposed to market risk in its trading activities, mortgage servicing rights, mortgage warehouse and pipeline, and equity holdings of The Coca-Cola Company common stock. The Asset/Liability Committee (ALCO) meets regularly and is responsible for reviewing the interest-rate sensitivity position of the Company and establishing policies to monitor and limit exposure to interest rate risk. The policies established by ALCO are reviewed and approved by the Company's Board of Directors.

\section{Market Risk from Non-Irading Activities}

The primary goal of interest rate risk management is to control exposure to interest rate risk, both within policy limits approved by the Board and within narrower guidelines established by ALCO. These limits and guidelines reflect SunTrust's tolerance for interest rate risk over both short-term and long-term horizons.

The major sources of the Company's non-trading interest rate risk are timing differences in the maturity and repricing characteristics of assets and liabilities, changes in relationships between rate indices (basis risk), changes in the shape of the yield curve, and the potential exercise of explicit or embedded options. SunTrust measures these risks and their impact by identifying and quantifying exposures through use of sophisticated simulation and valuation models, as well as repricing gap analysis.

The primary method that SunTrust uses to quantify and manage interest rate risk is simulation analysis, which is used to model net interest income from assets, liabilities, and derivative positions over a specified time period under various interest rate scenarios and balance sheet structures. This analysis measures the sensitivity of net interest income over a relatively short time horizon (two years). Key assumptions in the simulation analysis (and in the valuation analysis discussed below) relate to the behavior of interest rates and spreads, the changes in product batances and the behavior of loan and deposit customers in different rate environments. Material assumptions include the repricing characteristics and balance fluctuations of indeterminate, or noncontractual, deposits.

As the future path of interest rates cannot be known in advance, management uses simulation analysis to project net interest income under various interest rate scenarios including expected, or "most likely." as well as deliberately extreme and perhaps unlikely, scenarios. The analyses may include rapid ramping of interest rates, gradual ramping of interest rates, spread narrowing and widening, and yield curve twists. Usually, each analysis incorporates what management believes to be the most appropriate assumptions about customer behavior in an interest rate scenario, but in some analyses, assumptions are deliberately changed to test the Company's exposure to a specified event or set of events. Specific strategies are also analyzed to determine their impact on net interest income levels and sensitivities.

The following table reflects the estimated change in net interest income as a percent of net interest income forecasted under stable rates for the next twelve months oue to a gradual change in interest rates (25 basis points per quarter). Estimated changes set forth below are dependent on material assumptions such as those previously discussed.

\section{Estimated Changes in Net Interest Income}

\begin{tabular}{ccc}
$\begin{array}{c}\text { Rate Change } \\
\text { (Basis Points) }\end{array}$ & $\begin{array}{c}\text { Estimated \% Change in } \\
\text { Net Interest Income Over 12 Mantins }\end{array}$ \\
\hline & 2002 & 2001 \\
\hline+100 & $0.6 \%$ & $0.3 \%$ \\
-100 & $-0.9 \%$ & $-0.4 \%$
\end{tabular}

As indicated, a gradual 100 basis point decrease in interest rates would reduce net interest income, but by an amount that is within the policy limits. A gradual 100 basis point increase would tend to enhance net interest income. Thus, the Company's interest rate sensitivity position is modestly asset-sensitive. While simulations of more rapid changes in interest rates indicate more adverse changes in net interest income, the Company is still within the policy limits.

Estimated net interest income exposures at December 31 , 2002 differ from those at year-end 2001 , reflecting changes in the balance sheet, economic environment, and level of interest rates. The increase in the asset sensitive position from 2001 reflects the continued restructuring of the securities available for sale portfolio in 2002, which had the effect of reducing the duration of the pontfolio, as well as significant growth of low rate customer deposits (DDA and NOW's) that would not reprice or reprice very slowly in a rising rate environment.

SunTrust also performs valuation analysis, which is used for disceming levels of risk present in the balance sheet and derivative positions that might not be taken into account in the net interest income simulation analysis. Whereas net interest income simulation hightights exposures over a relatively shert time horizon, valuation analysis incorporates all cash flows over the estimated remaining life of all balance sheet and derivative positions. The valuation of the balance sheet, at a point in time, is defined as the discounted present value of asset cash flows and derivative cash flows minus the discounted value of liability cash flows, the net of which is referred to as EVE. The sensitivity of EVE to changes in the level of interest rates is a measure of the longer-term repricing risk and options risk embedded in the balance sheet. In contrast to the net interest income simulation, which assumes interest rates will change over a period of time, EVE uses instantaneous changes in rates. EVE values only the current balance sheet, and does not incorporate the growth assumptions that are used in the net interest income simulation model. As with the net interest income simulation model, assumptions about the timing and variability of balance sheet cash flows are critical in the EVE analysis. Particularly important are the assumptions driving prepayments and the expected changes in balances and pricing of the indeterminate deposit portfolios. As of December 31, 2002, an instantaneous 100 basis point increase in rates is estimated to increase the EVE $2.7 \%$ versus the EVE in a stable rate environment. An instantaneous 100 basis point decrease in rates is estimated to decrease the EVE $7.2 \%$ versus the EVE in a stable rate environment. These changes are within the established policy limits. As of December 31, 2001, these estimates were a $0.5 \%$ increase and a $2.7 \%$ decrease, respectively. 


\section{TESTING THE INFORMATION CONTENT OF EARNINGS-AT-RISK AND ECONOMIC VALUE OF EQUITY-AT-RISK PUBLIC DISCLOSURES}

\section{EAR}

The EARNINGS-AT-RISK measure represents an ex ante estimate of changes in earnings over the next twelve months should interest rate change by + or -100 basis points. This formulation of short-term interest sensitivity analysis is performed and disclosed by most financial institutions and facilitates comparisons between peers.

\section{EVEAR}

The ECONOMIC VALUE OF EQUITY-AT-RISK measure represents an ex ante estimate of net change between the present value of assets and the present value of liabilities should interest rate change by $+/-100$ basis points. This formulation of longer-term interest sensitivity analysis is also performed and disclosed by many financial institutions and further facilitates comparisons between peers.

\section{Proposed Testing Procedure}

We postulate that those institutions with the lowest (highest) ex ante relative EAR measures should display the lowest (highest) ex post relative changes in their earnings as a result of a given change in interest rate levels. To do so, the following equation is estimated :

$$
\frac{\Delta E_{t+1}}{E_{t}}=a+b \frac{E_{A R}}{E_{t}}
$$

Where $\Delta \mathrm{E}_{\mathrm{t}+1}$ measures the dollar change in net interest income from period $\mathrm{t}$ to period $\mathrm{t}+1, \mathrm{E}_{\mathrm{t}}$ measures the period $\mathrm{t}$ net interest income in dollars, $\mathrm{EAR}_{\mathrm{t}}$ represents the short-term interest rate risk dollar disclosure at period $\mathrm{t}$. Expressing both the 1.h.s. and r.h.s. of equation (1) in relative values allows comparisons to be carried out over time with the same institution, and between institutions which have different earnings. We propose to test equation (1) empirically using the OLS regression method.

As shown further on, our data sample consists of twenty North American commercial banks. Here, we postulate that those institutions with the lowest rank (highest rank) in their ex ante relative EAR measures should also display the lowest rank (highest rank) in their ex post relative changes in earnings as a result of a given change in interest rate levels. To do so, the following equation is estimated:

Rank (i) $\frac{\Delta E_{t+1}}{E_{t}}=a+b$ Rank (i) $\frac{E_{A R}}{E_{t}}$

Where Rank (i) varies from one (lowest ex ante relative EAR measure or lowest relative change in earnings) to twenty (highest ex ante relative EAR measure or highest relative change in earnings). Expressing both the 1.h.s. and r.h.s. of equation (2) in rank values allows more general comparisons to be carried out over time between institutions. We propose to test equation (2) empirically using the Spearman rank correlation coefficient.

Since the procedure for testing the information content of EAR and EVEAR public disclosure measures are practically similar, they are not repeated here for EVEAR.

\section{Sample Description}

To examine preliminary evidence on the information content of banks' EAR and EVEAR public disclosures. I composed a sample of some of North America's largest commercial banks. The Canadian bank peer group is based 
on Canada's seven largest domestic banks, and the U.S. peer group is composed of thirteen of its largest commercial banks. Table 1 shows for each bank in the data sample its ticker symbol, total assets expressed in U.S. dollars, senior long-term debt credit ratings, EAR and EVEAR annual data availability.

TABLE 1: DATA SAMPLE DESCRIPTION

\begin{tabular}{|c|c|c|c|c|c|c|}
\hline & Bank & $\begin{array}{l}\text { Ticker } \\
\text { Symbol }\end{array}$ & $\begin{array}{l}\text { Total Assets } \\
\text { U.S. (\$ Billions) }{ }^{1}\end{array}$ & $\begin{array}{l}\text { S\&P } \\
\text { S.L.T.D. } \\
\text { Ratings } 2\end{array}$ & $\begin{array}{l}\text { EAR } \\
\text { Year } \\
\text { Available }\end{array}$ & $\begin{array}{l}\text { EVEAR } \\
\text { Year } \\
\text { Available }\end{array}$ \\
\hline 1. & Bank of Montreal & BMO & $\$ 161,5$ & AA- & 1995 & 1995 \\
\hline 2. & CIBC & $\mathrm{CM}$ & $\$ 174,5$ & $\mathrm{~A}+$ & 1998 & 1998 \\
\hline 3. & Laurentian BoC. & LB & $\$ \quad 11,9$ & A- & 2000 & 2000 \\
\hline 4. & National BoC. & NA & $\$ \quad 47,6$ & A & 1999 & 1999 \\
\hline 5. & Royal BoC. & RY & $\$ 243,9$ & AA- & 1996 & 1996 \\
\hline 6. & Scotiabank & BNS & $\$ 189,2$ & A+ & 1996 & 1996 \\
\hline 7. & TD Bank & $\mathrm{TD}$ & $\$ 177,5$ & A+ & 1995 & 1995 \\
\hline 8. & Bank of America Corp. & BAC & $\$ 660,5$ & A+ & 1999 & Not disclosed \\
\hline 9. & Bank One Corp. & ONE & $\$ 277,4$ & A & 1997 & +/- disclosed \\
\hline 10. & Citigroup & $\mathrm{C}$ & $\$ 1097,2$ & AA & 1996 & 1998 \\
\hline 11. & Fleet Boston F. Corp. & FBF & $\$ 190,5$ & A & 1994 & 1996 \\
\hline 12. & JP Morgan Chase & JPM & $\$ 758,8$ & AA- & 1993 & +/- disclosed \\
\hline 13. & Key Corp. & KEY & $\$ 85,2$ & A & 1994 & +/- disclosed \\
\hline 14. & Mellon F. Corp. & MEL & $\$ 36,2$ & $\mathrm{~A}+$ & 1994 & Not disclosed \\
\hline 15. & National City Corp. & NCC & $\$ 118,3$ & A & 1993 & 1993 \\
\hline 16. & PNC F.S. Group & $\mathrm{PNC}$ & $\$ \quad 66,4$ & A- & 1997 & 1997 \\
\hline 17. & Sun Trust Banks & STI & $\$ 117,3$ & AA- & 2000 & 1999 \\
\hline 18. & US Bancorp. & USB & $\$ 180,0$ & A & 1997 & +/- disclosed \\
\hline 19. & Wachovia Corp. & WB & $\$ 341,8$ & A & 1993 & Not disclosed \\
\hline 20. & Wells Fargod Cy. & WFC & $\$ 349,3$ & $\mathrm{~A}+$ & 1994 & Not disclosed \\
\hline & dion boloct to & & were transla & $385 \mathrm{x}$ & an \$ into & funds. \\
\hline
\end{tabular}

TABLE 2: EAR RESULTS - CANADIAN BANKS

$\begin{array}{ccccl}\text { Variables } & \text { Value } & \text { F Test } & \text { T Test } & \text { Sig. } \\ \text { Regression } & \text { R.Sq. } & 4.528 & 0.041 & 12.1 \% \\ \text { a } & .0735 & & 1.430 & 0.162 \\ \text { b (std.) } & -0.3470 & & -2.128 & 0.041\end{array}$

As can be gathered from Table 1, the average size of the seven Canadian banks at $\$ 143$ B is not that different from the thirteen U.S. at \$329.1 B if we remove the three largest U.S. banks (BAC, C and JPM). It is also possible to compute the average default risk of the seven Canadian banks and to compare it to the average default risk of the thirteen U.S. banks. In order to carry out this analysis a bank's senior long-term debt credit rating is simply replaced by a number. For example, AAA equals 1 , AA+ equals 2 , AA equals 3 , AA- equals 4 , A+ equals 5 , A equals 6 , and A- equals 7. The Canadian bank sample has an average credit rating of 4,79; that is, a shade lower than the U.S. bank sample at 4,69. Also important is the fact that all twenty North American banks in our sample make EAR disclosures in their annual reports. All seven Canadian banks also make EVEAR disclosures in their annual reports. In the U.S. bank sample, four banks disclose EVEAR numbers, one other bank, Citigroup, discloses an equivalent number using another measure, four banks make sporadic disclosures, three banks do not disclose EVEAR numbers, and finally one bank (Mellon F. Corp.) carries out EVEAR computations but they are not disclosed in its annual report. Since EAR disclosures are more complete and frequent in our data sample than EVEAR disclosures, it stands to reason that more analysis can be carried with EAR disclosures in this study. 


\section{THE EMPIRICAL RESULTS}

The objective of the empirical tests is to examine if commercial banks' ex ante EAR numbers are related to ex post variations in net interest income for the complete bank sample, the U.S. bank sub-sample, and the Canadian bank sub-sample during the study period. Similar tests were also carried out to examine if commercial banks' EVEAR numbers were related to ex post variations in net interest income for the Canadian and U.S. sub-samples, and also the complete commercial bank sample.

OLS regression results indicate that ex ante EAR numbers were not closely related to ex post variations in net interest income for the complete bank sample and the U.S. bank sub-sample. As shown in Table 2 below, the results were only statistically significant for the Canadian bank sub-sample ( at the $96 \%$ level ).

In addition, OLS results also lead us to conclude that ex ante EVAR numbers were not closely related to ex post variations in net interest income for the complete bank sample, nor for the U.S. and Canadian bank sub-samples during the study period.

Given the general tone of the results presented above on ex ante EAR and EVEAR numbers and subsequently observed variations in commercial banks' net interest income, the Spearman rank correlation coefficient analysis which was proposed earlier was not carried out.

\section{CONCLUSIONS}

The study documents that EAR public disclosures were made in their annual financial reports by all commercial banks in our sample. In comparison, EVEAR public disclosures were made by all Canadian banks, but by only a fraction of U.S. banks in our sample. ALM managers use EAR as a short-term measure, and EVEAR as a longer-term measure of the dollar amount of potential loss to net interest income and common shareholders' equity as a result of unforeseen interest rate changes. These two interest rate risk management metrics are now recognized benchmarks for measuring the exposure to interest rate risk, and its potential impact on a bank's financial position. At the explicit request of regulators, financial analysts and competitive pressures, more commercial banks are now reporting EAR and EVEAR numbers in their annual financial reports. In addition, some banks like JPMorgan Chase in the U.S. have been reporting non-trading portfolio VaR numbers for investment portfolio and $\mathrm{A} / \mathrm{L}$ activities.

To examine preliminary evidence on the information content of such EAR and EVEAR public disclosures, we composed a sample of some of North America's largest commercial banks. The Canadian bank sub-sample is based on Canada's seven largest domestic banks, and the U.S. sub-sample is composed of twelve of its largest commercial banks. In particular, we investigated if ex ante EAR and EVEAR numbers help regulators, financial analysts and investors to explain the subsequent variability of commercial banks' net interest income and net income over time.

Unlike in Jorion's (2003) study of commercial banks' VaR public disclosures, the preliminary results presented in this paper indicated that banks' EAR and EVEAR public disclosures did not explain the subsequent variability of their net interest income over time. Canadian banks' EAR public disclosures were found to provide some indication of the subsequent variability of their net interest income during the period under study.

Data availability: The data used in this study can be obtained from public sources. 


\section{REFERENCES}

1. Basel Committee on Banking Supervision (BCBS ). 2004. Principles for the Management and Supervision of Interest Rate Risk. Basel, Switzerland: BIS.

2. Basel Committee on Banking Supervision ( BCBS ). 2003. Public Disclosures by Banks: Results Of the 2001 Disclosure Survey. Basel, Switzerland: BIS.

3. Basel Committee on Bank Supervision. 2003a. Overview of the New Basel Capital Accord: Consultative Document (April).

4. Basel Committee on Bank Supervision. 2003b. Public Disclosures by Banks: Results of the 2001 Disclosure Survey. Basel Committee Publications No. 97 (May).

5. Berkowitz, J. and J. O'Brien. 2001. How accurate are the value at risk models at commercial banks? Working paper, Board of Governors of the Federal Reserve System.

6. Board of Governors of the Federal Reserve System. 2000. Improving Public Disclosure in Banking. Staff Study \# 173.

7. Board of Governors of the Federal Reserve System. 2001. Supervisory Letter 01-06: Enhancements to Public Disclosure.

8. Christofferson, P., J. Hahn, and A. Inoue. 2001. Testing, comparing, and combining value at risk measures. Journal of Empirical Finance 8 (July): 325-342.

9. Jorion, P. 2002. How Informative Are Value-at-Risk Disclosures? The Accounting Review 77 ( October ): 911-931.

10. Jorion, P. 2003. How Informative Are Value-at-Risk Disclosures? The Accounting Review 77, pp. 911-931.

11. Kwan, Simon H. 2002. The Promise and Limits of Market Discipline in Banking. FRBSF Economic Letter 2002-36 (December 13).

12. Kwan, Simon H. 2002. Bank Security Prices and Market Discipline. FRBSF Economic Letter 2002-37 (December 20).

13. Linsmeier, T., D. Thornton, M. Venkatachalam, and M. Welker. 2002. The effect of mandated market risk disclosure on trading volume sensitivity to interest rate, exchange rate, and commodity price movements. The Accounting Review 77 (April): 343-378.

14. Lopez, Jose A. 2003. How Financial Firms Manage Risk. FRBSF Economic Letter 2003-03 (February 14).

15. Lopez, Jose A. 2003. Disclosure as a Supervisory Tool: Pillar 3 of Basel II. FRBSF Economic Letter 2003-22 (August 1).

16. Wong, F. 2000. The association between SFAS No. 119 derivatives disclosures and the foreign exchange risk exposure of manufacturing firms. Journal of Accounting Research 38 (Autumn): 387-417. 


\section{NOTES}

